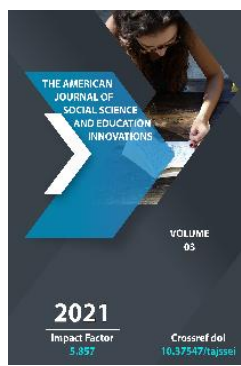

\title{
Trade Impacts Of The Us Anti-Dumping Actions: A Case Study Of Vietnam
}

Lan Anh Le

VASS Institute Of American Studies, Hanoi, Vietnam

Journal Website:

http://usajournalshub.c om/index,php/tajssei

Copyright: Original content from this work may be used under the terms of the creative commons attributes 4.0 licence.

\section{ABSTRACT}

Anti-dumping is among of the important trade protection measures that imported countries use against oversea enterprises. The United States is considered one of the most countries use antidumping measures to protect the domestic product market from the foreign competitors exporting identical or similar products into the US market. Vietnam's exporters also have to face the US antidumping investigations, becoming a barrier to the favorable trade flow from Vietnam to the United States. This article uses the data on trade between the US and Vietnam for many years to takes a close look at the importance of promoting and developing bilateral trade between the two countries; as well as point out the remarkable changes of Vietnam's export to the US before and after initiating antidumping investigations. Based on the importance of bilateral trade cooporation and the impacts of the US anti-dumping actions to Vietnam's export, this article gives several implications to Vietnamese exporters to avoid the US antidumping investigations.

\section{KEYWORDS}

Vietnam, dumping, the U.S. anti-dumping, trade, investigation, recommendation

\section{INTRODUCTION}

Economic integration has brought many opportunities to expand export and import markets for countries worldwide. However, it also emerges unfair competition activities, such as dumping action. In several cases, dumping is considered illegal and imposed anti- 
dumping measures. Anti-dumping is among of the important trade protection measures that imported countries use against oversea enterprises. The United States is considered one of the most countries use anti-dumping measures to protect the domestic product market from the foreign competitors exporting identical or similar products into the US market. Being one of the largest importers of the United States (US), Vietnamese goods takes the best opportunities of satisfying this tough competitive market. However, along with the opportunities, Vietnamese goods also has to face many US anti-dumping investigations, becoming a barrier to the favorable trade flow from Vietnam to the United States. The objectives of this article are clarying the concepts of "Dumping and Antidumping" in international trade; using data of anti-dumping investigation surveys of the US against Vietnamese goods under suspicion of dumping to analyse the trade effects of the US anti-dumping lawsuits on Vietnam' exporting activity. Moreover, several recommendations could be useful for Vietnam's exporters to avoid being initiate anti-dumping from the US.

\section{RESULTS}

\section{Dumping and Anti-dumping}

The concept of "Dumping" has been studied since 1922 by the Association of Nations (League of Nations). However, until 1947, the concept of dumping was put under the control of common international law in the Article VI of General Agreement on Tariffs and Trade (GATT). According to Article VI: “... dumping, by which products of one country are introduced into the commerce of another country at less than the normal value of the products, is to be condemned if it causes or threatens material injury to an established industry in the territory of a contracting party or materially retards the establishment of a domestic industry..." ". Based on the content of Article VI of GATT, dumping is not considered illegal. It only turns into illegal and is initiated to anti-dumping action when it causes or threatens to cause material injury to an established industry of a importing country. To prevent dumping, governments of importing countries take measures to deal with and even retaliate to maintain a healthy competitive environment, protect domestic industry, (Hang V., T., N. 2014).

Anti-dumping refers to the measures taken by one country against dumping of products from foreign countries or regions in its domestic market. When a dumping brings harm to the industry and market of the importers, the importing country can initiate an investigation, impose antidumping duties if necessary, and adopt other measures to restrict the imports of relevant products, (Blonigen A., B. et al. 2001).

Although anti-dumping measures are classified as non-tariff measures, they are in fact often enacted as part of the tariff law, using a remedy like tariffs. The result of anti-dumping actions are to impose anti-dumping duties on goods under investigation. Even if having no tariffs are ultimately imposed, the relevant administrative procedures by themselves are sufficient to have detrimental effects on importing goods.

\section{Overview of the US anti-dumping actions against Vietnam}

Trade cooperation between Vietnam and the US has made significant progress, particularly since Bilateral Trade Agreements (BTA) between the two countries was signed and took effect from Octorber 12, 2001, has created the first official legal framework to promote 
The American Journal of Social Science and Education Innovations (ISSN - 2689-100x)

Published: April 22, 2021 | Pages: 111-117

Doi : https://doi.org/10.37547/tajssei/Volume03Issue04-17

development of Vietnam-US trade cooporation. Before having the BTA, trade bilateral turnover between the US-Vietnam rose from 450 million USD (1995) to 1.09 billion USD (2000); However, since the BTA came to effect, trade turnover has so far increased from nearly 1.2 billion USD in 2000 to 6.75 billion USD in 2005, then reached 18.10 billion USD in 2010, and increased to 29.7 billion USD in 2013, according to the report of United States Census Bureau, 2019. Trade bilateral turnover continued to gain at a high level with 41.28 billion USD in 2015, 75.72 billion in 2019, 75 times higher than in 2000, (Mai N. 2020). In particular, Vietnam 's export turnover of goods to the United States in 2000 was 0.733 billion USD, in 2005 was 5.93 billion USD, in 2010 was 14.24 billion USD, in 2015 was 33.48 billion USD, and in 2019 reached to 61.35 billion USD. By the end of April 2020, the total export turnover of Vietnam to the US reached 20.16 billion USD, up $12.9 \%$ over the same period of 2019 , equivalent to an increase of over 2 billion USD, (Tran T. 2020).

In 2019, the United States has become the largest importer of Vietnam's products, followed by China and the EU, (Trinh N., 2020). Moreover, Vietnam has also become the 7 th largest exporter of products to the US market and become the 5 th largest country with a trade surplus with the United States was 54.5 billion USD (United States Census Bureau, 2019). Vietnam's main exports to the US market over the past several years include textiles, seafood, wood products, garments, machineries, etc. Among of them, textiles and garments are considered as the main export items of Vietnam to the United States. Recently, the United States has become the largest textile and garment export market of Vietnam, accounting for 14.85 billion USD in total export turnover was 38.9 billion USD in 2019 , equivalent to $39 \%$ of the export value of the whole industry. In the first two months of 2020, textile and garment exports to the US reached 2.25 billion USD, up 5.3\% over the same period of 2019 and accounting for nearly $48 \%$ of the country's total textile export value, (Vietnamese Goverment Portal, 2020).

Taking the advantage of low infrastructure expenses, raw materials and labor, Vietnamese goods has competitive price with goods of other countries. Among the top No.5 of the US import suppliers from ASEAN countries in 2018, Vietnam was the first rank with 49.2 billion USD, followed by Malaysia (39.4 billion USD), Thailand (31.9 billion USD), Singapore (27.3 billion USD) and Indonesia (20.9 billion USD).

These positive indicators can be seen that, since the two countries normalized diplomatic relations, especially since the BTA was signed and took effect, the trade relations between Vietnam and the US have made much significant progress, especially on the side of Vietnam. This is one of the important pillars in promoting the long-term comprehensive and stable partnership between the two countries, bringing the bilateral relationship to a new high level.

However, because of the precise advantages of competitive elements, merchandise exports of Vietnam has been already under many investigations in the US market for allegedly committing of dumping, and being imposed anti-dumping lawsuits typically frozen shrimp, catfish, cold-rolled steel cases, etc. These antidumping investigations have caused negative impacts to the export activities of Vietnam, affected to the ability of competing in international trade, especially in the context of Vietnam is still considered "non-market 
economy" by the US and EU, (Dong P., K., T. 2012).

According to a report of Vietnam Chamber of Commerce and Industry ( $\mathrm{VCCl}$ ), there are 109 cases of anti-dumping investigations against Vietnam goods in foreign markets, including 20 cases initiated by the United States. The first anti-dumping investigation initiated by the US against Vietnamese exporters was catfish case in 2002. The second one was about frozen warm-water shrimp in 2003. These are the first two anti-dumping investigations, taking place in a row and with the longest administrative reviews. As of early 2021, catfish case has been taken the 15th administrative review (POR15) on April 20, 2020. The most recent antidumping investigation conducted by the United States was for automobile tires from Vietnam, Korea, Thailand, and Taiwan on November 17, 2020.

Among 20 anti-dumping investigations conducted by the US against Vietnamese exporters, there were 6 double lawsuits (both anti-dumping and countervailing). These were the investigations filed against Polyethylene Retail Carrier Bags in 2009; Certain Steel Pipe in 2011; Steel wire garment hanger in 2012; Steel nails in 2014; Laminated Woven Sacks (LWS) in 2018; and 2020 was Mattress case. In particular, there is only one case where the plaintiff voluntarily withdrawed the lawsuit was Fine Denier Polyester Staple Fiber case in 2017.

\section{The impacts of US anti-dumping actions on Vietnam's exports}

It can be clearly seen that anti-dumping actions of the US cause great damage to the Vietnam's manufacturing and exporting enterprises, even in investigation periods or after being imposed anti-dumping duties. There is a fact that, when an exporter is in a trouble with an anti-dumping investigation, before and during the investigation process, the number of orders from the country under investigation decreased significantly, adversely affecting, (Quang M., V. 2016). As a result, they have to start looking for new supplies from other countries on fears that an anti-dumping lawsuit will lead to high additional tariffs. Their trade activities therefore meet difficulties in the contracted partner's market. In 2002, for the first time, Vietnam's pangasius production faced an anti-dumping investigation by the American Catfish Farmers Association (CFA). Because of having no experience in responding before, Vietnam's pangasius production could not bear taxes and costs after the first administrative review (POR1). As the result, export turnover of pangasious product had to be felt down remarkably following years to the US market. Pangasious businesses struggled in finding other markets.

Futhermore, in order to pursue a lawsuit, Vietnamese defendants are under cost and time pressure of related investigation proceedings (for example, hiring lawyers, taking time to answer questionnaires, consult hearings, lobbyists, etc.). These costs are not always affordable for all defendants.

Being categorized as a non-market economy like China, the final anti-dumping duties for Vietnamese defendants are often negative (Vermulst E. et al. 2016). In 2017, the US decided to extend the time to impose anti-dumping duty on Vietnamese tra and basa fish export for up to 5 years. On March 9, 2018, the US decided to apply anti-dumping tax for Vietnamese shrimp products in the period of 2016 - 2017 of $25.39 \%$. This is a rather high tax rate that shrimp exporting enterprises suffer when exporting to the US. This tax is part of the reason that the import turnover into the US market has 
decreased significantly in recent years. From the No. 1 position in 2016, shrimp export turnover to the US has dropped sharply, falling to the 4th position among the top export markets of Vietnam shrimp. In addition to the exported seafood products, in early November 2017, the US officially announced the imposition of anti-dumping tax on tool cabinets imported from Vietnam with the tax that the Vietnamese side suffered up to $230 \%$, even higher than the $90.4-168.93 \%$ that Chinese enterprises suffer.

In March 2018, the US Department of Commerce issued the final decision on the 13th administrative review of anti-dumping duty on frozen tra and basa fillets imported from Vietnam between August 1, 2015 and January 31. July 2016, in which the US decision tax rate was 1.6 times higher than the rate that the United States made in the preliminary decision in September 2017 and was 4.9 times higher than the private tax rate. During the 12th administrative review period. From May 14-25, 2018, the US Food Safety Inspection Agency began conducting a practical inspection of Vietnam's catfish control program, (Chung K., T. et al. 2018). In the first 9 months of 2017, Vietnam's tra and basa fish exports to the US decreased by $9.9 \%$ compared to the first 9 months of 2016 and continued to decrease in the last months of the year, (Cong X., L et al. 2018). With the US imposing high anti-dumping duties on this product, the export of catfish from Vietnamese enterprises to the US market is becoming more and more difficult. Being imposed high anti-dumping duties not only on pangasious produtct, but also on many other Vietnam's exporting products for example, margin of dumping was $116,31 \%$ in Uncovered innerspring units case in 2008, anti-dumping duty was from $157.00 \%$ to $220.68 \%$ in Steel wire garment hanger case in 2012, (Center for WTO and Integration - VCCl, 2020).

These anti-dumping duty pressures can make enterprises difficult to compete and export. They may have to stop production or even go bankrupt, leading to serious unemployment. The related input supply industries and foreign investment in the defendant industry were also significantly affected. The bad thing is that these adverse consequences can last for many years (because an anti-dumping tax measure lasts at least 5 years and can be extended many times then).

\section{CONCLUSION AND RECOMMENDATIONS}

To avoid the US anti-dumping investigations, these following measures should be done effectively:

- Solutions to improve the law related to the organization of operation of exporting enterprises: There are many anti-dumping cases pointed out that despite having careful preparation, Vietnamese export companies still risk facing unpredictable investigations and the disputes on antidumping. When such incidents occur, usually exporting companies will be parties suffered the most damage from the requirements on procedures for investigating cost, long-term disputes and their reputation in the US market.

- Vietnamese companies themselves still need to be well prepared to minimize the damage. Vietnamese exporters need to standardize and maintain transparency of accounting system and Certificate of Origin; comprehensive understanding and strictly enforcing international legal regulations and procedures on anti- 
dumping in general as well as the US antidumping regulations and laws in particular; ensure the strict legality of trade contracts with the US partners in order to ensure the smooth completion of DOC questionnaire as well as obtain all available evidence for the lawsuit investigation process requirement; Every of involved parties needs to be well aware of the positive role of participating in the lawsuit to avoid being deemed uncooperated by antidumping investigating authorities, leading to high anti-dumping duty.

- Broaden of signing the trade agreement bilateral and multilateral with other countries and regions in order to expand as well as promote the potential export markets, avoid depending a specific export market; there should be more and more policies of dealing with the output of stored products during being dumped period; complete the early warning system for the risk of anti-dumping investigations.

\section{REFERENCES}

1. Blonigen A., B. and Prusa J., T. (2001). Antidumping. National Bureau of Economic Research. NBER Working Paper No. w8398, July 2001.

2. Center for WTO and Integration - VCCl. (2020). Statistics of anti-dumping investigations against Vietnamese goods in foreign markets as of December 31, 2020. https://chongbanphagia.vn/thong-ke creation-for-to-the-country-from-flowerto-flower-from-Vietnam-to-Market-fromto-Country-to-31122020-n22469.html service

3. Chung K.., T. and Phan N., T. (2018). The motivational role of the private economy in Vietnam's economic development, "Vai trò động lực của kinh tế tư nhân trong phát triển kinh tế Việt Nam”. Finance Magazine. Volume (Issue): 01,2018.

4. Cong X., L. and Dung T., V. (2018). The leading role of the State economy in the socialist market economy, "Vai trò chủ đạo của kinh tế nhà nước trong nền kinh tế thị trường định hướng xã hội chủ nghĩa". Journal of State Organization. Available online:

http://tcnn.vn/news/detail/39106/Vai_tro_c hu_dao_cua_kinh_te_nha_nuoc_trong_ne n_kinh_te_thi_truong_dinh_huong_xa_ho i_chu_nghiaall.html (accessed on 12th March, 2018).

5. Dong P., K., T. (2012). The Impacts of NonTariff Bariers on the Export Price of Vietnamese Catfish. The Norwegian College of Fishery Science University of Tromso. Norway \& Nha Trang University, Vietnam.

6. Vermulst E., Sud D., J. and Evenett J., S. (2016). Normal Value in Anti-Dumping Proceedings against China Post-2016: Are Some Animals Less Equal Than Others?. https://www.alexandria.unisg.ch/253037/1/ GTCJ2016030.pdf

7. Hang V., T., N. (2014). Comparison of antidumping laws between Vietnam and the United States, "So sánh pháp luật về chống bán phá giá hàng hóa giữa Việt Nam và Hoa Kỳ", Vietnam University of Hanoi., 2014

8. Mai N. (2020). The US-Vietnam Investment and Trade Relations for a Quarter of Century. "Quan hệ thương mại và đầu tư Việt - Mỹ trong $1 / 4$ thế kỷ”. http://tapchitaichinh.vn/nghien-cuu-traodoi/quan-he-thuong-mai-va-dau-tu-viet-mytrong-14-the-ky-324712.html

9. Quang V., M. 2016. The US anti-dumping policy and the effects on Vietnam's exports, “Chính sách chống bán phá giá của Mỹ và những ảnh hưởng đến hàng hóa 
xuất khẩu của Việt Nam". Vietnam University of Hanoi, 2014.

10. Tran T. (2020). Total export turnover to the USS reached 20.16 billion USD. (Tổng kim ngạch xuất khẩu sang Mỹ đạt 20,16 tỷ USD). http://cand.com.vn/Thi-truong/Tong-kimngach-xuat-khau-sang-My-dat-20-16-tyUSD-596755/

11. Trinh N. (2020). Vietnam Rises to Second Spot in Share of US Imports: Jungle Scout. vietnam-briefing. Accessed on March 03, 2021. https://www.vietnambriefing.com/news/vietnam-rises-secondspot-in-share-us-imports-junglescout.html/

12. United States Census Bureau. (2019). Trade in Goods with Vietnam. https://ustr.gov/countries-

regions/southeast-asia-

pacific/vietnam\#: :text=The\%20U.S.\%20go ods\%20and\%2oservices,was\%20\%2454.5\%20 billion\%20in\%202019.\&text=Goods\%20expo rts\%2ototaled\%20\%2410.9\%2obillion,estimat ed\%20\%243.8\%2obillion\%20in\%202019.

13. Vietnamese Goverment Portal. (2020). The United States does not have a policy of suspending imports of Vietnamese textile and apparel products, "Hoa Kỳ không có chủ trương tạm ngừng nhập khẩu sản phẩm dệt may Việt Nam". Accessed on March 25, 2020. http://baochinhphu.vn/Kinh-te/Hoa-Kykhong-co-chu-truong-tam-ngung-nhapkhau-san-pham-det-may-VietNam/390515.vgp.

14. Center for WTO and Integration - VCCI. (2020). Statistics of anti-dumping investigations against Vietnamese goods in foreign markets as of December 31, 2020. https://chongbanphagia.vn/thong-ke creation-for-to-the-country-from-flowerto-flower-from-Vietnam-to-Market-from-
to-Country-to-31122020-n22469.html service 